\title{
EFISIENSI PEMASARAN MELALUI MINIMASI JALUR DISTRIBUSI SUSU SEGAR SAPI PERAH DI KECAMATAN MOJOSONGO KABUPATEN BOYOLALI
}

\author{
Ayu Intan Sari*, Sutrisno Hadi Purnomo, Shanti Emawati, Endang Tri Rahayu, \\ Bayu Setya Hertanto dan Muhammad Abdul Haris \\ Program Studi Peternakan, Fakultas Pertanian, Universitas Sebelas Maret \\ *Corresponding author: ayuintan@staff.uns.ac.id
}

\begin{abstract}
Fresh milk is highly nutritious food because its contain substances that complete food. The high nutritional value of milk causes a media which is preferred by the microorganisms to grow and develop in a very short time become unfit milk consumed when handled incorrectly. Safety milk from contamination during the distribution process becomes very important because of a race against time. Considering the conditions on the farm people milk distribution process normally without treatment (cooling), so that the required distribution by the shortest route, the fastest time and low cost. This study aims to minimize lines and distribution costs of fresh milk as marketing efficiency efforts. The research location is taken purposively based on the consideration that the District Mojosongo has the second largest population of dairy cows in Boyolali. The analytical method used is the analysis of marketing costs, margins and profit marketing, marketing efficiency and Traveling Salesman Problem analysis to determine the shortest distance, fastest time and lowest cost. Fresh milk marketing channels used dairy producers in the district Mojosongo there are three channels following the channel I: Farmer to Consumer, Channel II: Farmers to Traders collector to Consumer and Channels III: Farmers to Traders collector to wholesaler to the milk processing industry. Channel I is the most efficient marketing channel because this channel sells directly from farmers to consumers. The most effective marketing channels using the Travelling Salesman Problem is the distribution channels II because this path has the shortest distance, fastest time to maintain the quality of fresh milk and cost efficiency.
\end{abstract}

Keywords: Dairy cattle fresh milk; Marketing channel; Marketing efficiency; Marketing margin, Traveling salesman problem

Cite this as: Sari, A.I., Purnomo, S.H., Emawati, S., Rahayu, E.T., Hertanto, B., \& Haris, M. 2017. Efisiensi Pemasaran melalui Minimasi Jalur Distribusi Susu Segar Sapi Perah di Kecamatan Mojosongo Kabupaten Boyolali. Caraka Tani: Journal of Sustainable Agriculture. 32(1), 42-48. doi: http://dx.doi.org/10.20961/carakatani.v32i1.15082

\section{PENDAHULUAN}

Susu segar merupakan bahan pangan yang bergizi tinggi karena mengandung zat-zat makanan yang lengkap dan seimbang seperti protein, lemak, karbohidrat, mineral, dan vitamin yang sangat dibutuhkan oleh manusia. Nilai gizinya yang tinggi juga menyebabkan susu merupakan medium yang sangat disukai oleh mikroorganisme untuk pertumbuhan dan perkembangannya sehingga dalam waktu yang sangat singkat susu menjadi tidak layak dikonsumsi bila tidak ditangani secara benar (Ernawati, 1996). Keamanan susu terhadap kontaminasi kuman selama proses distribusi menjadi sangat penting karena berpacu dengan waktu. Mempertimbangkan kondisi pada peternakan rakyat proses distribusi susu biasanya tanpa perlakuan (pendinginan), sehingga diperlukan distribusi dengan rute terdekat, waktu tercepat dan biaya rendah.

Kabupaten Boyolali merupakan salah satu daerah di Provinsi Jawa Tengah dengan populasi ternak sapi perah dan produksi susu terbesar, yaitu dengan populasi pada tahun 2013 sejumlah 88.533 ekor, dengan produksi susu sebesar 48.075.220 liter (BPS, 2014). Predikat sebagai "Kota Susu" masih tetap dipertahankan oleh kabupaten yang merupakan daerah utama penghasil susu di Provinsi Jawa Tengah dan termasuk ke jalur susu 
yaitu jalur Semarang-Boyolali-Klaten-Solo. Produksi susu sapi di Boyolai masih belum mampu memenuhi permintaan Industri Pengolahan Susu (IPS) yang saat ini mencapai 250 ton per hari, saat ini produksi baru mencapai 120 ton. Artinya permintaan produk susu sapi Boyolali sangat tinggi. Produksi susu sapi Boyolali memasok bahan baku untuk empat IPS besar yang ada di Boyolali dan Salatiga, diantaranya PT. Indolakto dan PT. Frisian Flag Indonesia.

Menurut ketua GKSI Jateng-DIY pengelolaan usaha peternakan sapi perah di provinsi JatengDIY berbeda dengan provinsi Jabar dan Jatim yang sudah paham keuntungan usaha ternak sapi perah. Mereka memberi pakan dengan benar dan berkualitas sehingga kualitas susu yang dihasilkan bagus, dan akhirnya harga juga menjadi meningkat. Disini peternak memelihara sapi hanya sebagai sampingan dengan sistem pemeliharaan tradisional. Kualitas susu yang rendah memang menjadi persoalan. Jumlah kuman yang sesuai standar nasional Indonesia maksimal 1 juta per milliliter, sementara di Boyolali angka kuman berkisar 1-5 juta per milliliter, hal ini menurut Kepala Dinas Peternakan dan Perikanan Kabupaten Boyolali salah satunya disebabkan kesulitan air didaerah tersebut. Selain kualitas, rendahnya harga susu juga disebabkan peternak tidak memiliki posisi tawar (bargaining power) yang baik, karena mereka bergerak secara individual. Peternak pada posisi yang lemah, karena harga ditentukan oleh pengepul. Hal ini dapat diantisipasi dengan pembentukan kelompok ternak, sehingga suara peternak dalam menawar harga akan lebih tingi.

Minimasi biaya distribusi juga harus dilakukan oleh peternak yang diharapkan mampu untuk memberikan keuntungan yang maksimal. Penentuan rute pengiriman yang terpendek adalah merupakan salah satu cara untuk meminimasi biaya distribusi susu dari peternak sebagai produsen ke pihak konsumen. Penentuan rute terpendek bermanfaat untuk meminimasi jarak tempuh dan untuk menjaga kualitas produk hingga sampai ke tangan konsumen dalam keadaan yang masih segar. Mengingat peternak mempunyai beberapa tujuan distribusi yang berlokasi di wilayah pemasaran. Dengan banyaknya alternatif perjalanan harian yang mungkin untuk dilewati dalam mendistribusikan produk susu ke wilayah tujuan yang memerlukan biaya distribusi yang besar, sehingga perlu memilih rute perjalanan yang cepat dan memerlukan biaya distribusi yang sedikit. Dengan latar belakang tersebut maka diperlukan suatu penelitian untuk meminimisasi jalur distribusi dengan menentukan rute perjalanan terpendek sehingga efisiensi pemasaran tercapai dan kualitas susu tetap terjaga.

\section{METODE PENELITIAN}

Penelitian ini dilaksanakan di Kecamatan Mojosongo pada tanggal 19 November tahun 2015. Metode dasar yang digunakan dalam penelitian ini adalah metode survey, yaitu penelitian dengan menggunakan pertanyaan terstruktur atau sistematis yang sama kepada banyak orang. Penelitian ini menggunakan metode pengambilan sampel peternak secara sengaja (purposive sampling) pada sampel produsen yaitu dipilih sebanyak 60 responden dari 968 peternak sapi perah. Pengambilan sampel ini berdasarkan desa yang memiliki populasi sapi perah tertinggi di Kecamatan Mojosongo yaitu berada di Desa Singosari.

\section{Desain Penelitian}

Penelitian ini menggunakan metode campuran (mixed method) kualitatif dan kuantitatif untuk mendapatkan hasil yang lebih komprehensif. Metode kualitatif merupakan penelitian yang berdasarkan filsafat yang digunakan untuk meneliti pada kondisi suatu obyek yang bukan alamiah, bukan suatu eksperimen, dimana peneliti adalah instrument kunci. Metode kuantitatif merupakan penelitian yang lebih menekankan pada aspek pengukuran obyektif terhadap fenomena sosial, yang dijabarkan ke dalam beberapa indikator, setiap variabel yang ditentukan diukur dengan memberikan simbol angka.

\section{Analisis Data}

Analisis data yang digunakan dalam penelitian ini adalah analisis biaya pemasaran, analisismargin pemasaran, analisis keuntungan pemasaran, efisiensi pemasaran dan analisis Traveling Salesman Problem (TSP) susu segar sapi perah di Kecamatan Mojosongo, dengan menentukan jarak, waktu dan biaya minimum. Metode analisa yang digunakan dalam menganalisis data untuk memperoleh hasil minimal dari transportasi produk adalah dengan menggunakan Travelling Salesman Problem 
(TSP) dengan tahapan KTT Maju Terus sebagai pengepul susu segar dari peternak anggota, kemudian mengirim susunya ke KUD Boyolali, PT. Indolakto, dan PT. Madrakila. Untuk itu didalam pemecahannya menggunakan pendekatan heuristik. Proses dimulai dengan memberi nomor terlebih dahulu dari konsumen 1 melalui $n$. Dengan konsumen 1 ditandai sebagai konsumen awal. Dengan penandaan jarak antara konsumen i ke konsumen $\mathrm{j}$ maka total jarak cij.

Penetuan jarak tempuh, waktu dan biaya distribusidengan menggunakan metode Travelling Salesman Problem (TSP) pemecahannya dengan menggunakan metode heuristic, yang hasilnya hamper mendekati optimal (Turner, 1993 dalam Utomo et al., 2004).

Metode yang paling sederhana dari pendekatan heuristic, dengan pendekatan konsumen terdekat yang belum dikunjungi, prosedurnya adalah: a) Melihat peta jaringan distribusi yang mempunyai jarak terpendek dimasukkan kedalam tabel; b) Berdasarkan tabel data yang berbentuk matriks diolah menggunakan metode TSP dengan pendekatan heuristik dengan langkah-langkah sebagai berikut:

1. Langkah 1, dengan melihat baris secara horizontal pada tabel mencari jarak yang terpendek dari sumber;

2. Langkah 2, dengan melihat secara vertikal pada titik langkah1 mencari jarak terpendek;

3. Langkah 3, mengulangi langkah 1 dan 2, sampai semua konsumen dilewati, kemudian mencari solusi dengan waktu perjalanan paling dekat, waktu paling singkat, serta biaya termurah dari sumber. Jika ada yang mempunyai nilai yang sama maka memilih salah satu.

\section{HASIL DAN PEMBAHASAN}

\section{Keadaan Pemasaran Susu di Kecamatan Mojosongo}

Potensi sektor peternakan sapi perah di Kecamatan Mojosongo merupakan aset penting yang perlu dikembangkan secara terarah, terpadu dan berkesinambungan serta diharapkan dapat menunjang kelanjutan pembangunan dalam kapasitasnya sebagai sumber protein hewani yang kaya gizi sebagai sumber pendapatan. Jenis ternak ruminansia yang paling banyak dibudidayakan sebagai usaha peternakan oleh masyarakat Kecamatan Mojosongo adalah ternak sapi perah yaitu sebanyak 15.247 ekor. Desa yang memiliki populasi ternak sapi perah terbanyak adalah Desa Singosari sedangkan populasi yang terendah berada di Desa Dlingo (BP3K Kecamatan Mojosongo, 2015).

Pemasaran susu segar sapi perah di Kecamatan Mojosongo memiliki beberapa kendala pemasaran seperti kualitas susu yang cepat menurun, lama pengiriman dan mahalnya biaya transportasi sehingga diperlukan saluran pemasaran yang cepat, efisien dan tidak memakan waktu yang lama. Saluran pemasaran yang baik berguna untuk mengatasi permasalahan kualitas susu segar yang cepat menurun. Saluran pemasaran menurut segi waktu dan biaya sebagian besar belum jelas tingkat efisiensinya, seperti halnya saluran pemasaran susu segar di Kecamatan Mojosongo Kabupaten Boyolali.

Perilaku pasar adalah pola perilaku dari lembaga tataniaga yang menyesuaikan dengan struktur pasar dimana lembaga tersebut melakukan suatu perdagangan (Permadi, 2008).

\section{Pembentukan harga Susu Segar}

Jenis dan kualitas susu yang dijual harus berdasarkan susu yang telah diuji sehingga terdapat grade yang bervariasi mulai dari grade A harga beli Rp 4.600,00, grade B harga beli $\mathrm{Rp} 4.400,00$ dan grade $\mathrm{C}$ harga beli $\mathrm{Rp}$ $4.200,00$. Salah satu ujinya menggunakan laktodensimeter yaitu untuk mengetahui berat jenis susu segar. Berat jenis susu segar umumnya $1,027-1.035 \mathrm{~g} / \mathrm{v}$ dengan rata-rata $1.031 \mathrm{~g} / \mathrm{v}$. Kemudian dilakukan juga uji rasa, bau dan warna oleh pedagang pengumpul. Sehingga hasil uji susu segar yang dilakukan pedagang pengumpul dapat dibagi menjadi 3 grade yaitu grade $\mathrm{A}$, grade $\mathrm{B}$ dan grade $\mathrm{C}$. Peternak sapi perah di Kecamatan Mojosongo rata-rata memiliki susu segar dengan kualitas susu grade $\mathrm{B}$.

\section{Pembelian dan penjualan Susu Segar}

Penjualan susu segar dilakukan oleh peternak sapi perah pada pagi hari pukul 05.00 - 07.00 WIB dan siang hari pukul 14.00 - 15.00 WIB. Tempat penjualan susu segar oleh peternak berada di pos-pos yang sudah ditentukan oleh pedagang pengumpul. Pedagang pengumpul melakukan uji terhadap susu segar sebelum membeli dan harga sesuai grade yang telah ditentukan. Peternak lebih memilih menjual susu segar ke pedagang pengumpul dengan alasan tidak repot, tidak 
ada resiko tidak laku seperti jika dibawa kepasar, tidak mengeluarkan biaya transportasi dan harga yang ditentukan peternak tidak jauh berbeda.

\section{Sistem pembayaran Susu Segar}

Pedagang pengumpul mendatangi peternak untuk membeli susu segar tiap harinya, kemudian jumlah susu segar tersebut dicatat oleh pedagang pengumpul. Sistem pembayaran yang dilakukan pedagang pengumpul kepada peternak yaitu 10 hari sekali secara tunai. Sistem pembayaran sususegar ada dua yaitu pembayaran tunai dan pembayaran tidak tunai.

\section{Saluran Pemasaran Susu Segar Sapi Perah di Kecamatan Mojosongo}

Susu segar di Kecamatan Mojosongo dipasarkan melalui 3 saluran pemasaran. Saluran pemasaran tersebut adalah: (1) Peternak $\rightarrow$ Konsumen, (2) Peternak $\rightarrow$ Pedagang pengumpul $\rightarrow$ Konsumen, (3) Peternak $\rightarrow$ Pedagang pengumpul $\rightarrow$ Pedagang besar $\rightarrow$ Industri pengolahan susu.

Tabel 1. Jumlah Peternak pada masing-masing Saluran Pemasaran Ternak Sapi Perah di Kecamatan Mojosongo, Kabupaten Boyolali

\begin{tabular}{cccc}
\hline No. & Saluran pemasaran & Jumlah Peternak & Presentase $(\%)$ \\
\hline 1. & I & 8 Orang & 13,3 \\
2. & II & 22 Orang & 36,7 \\
3. & III & 30 Orang & 50,0 \\
\hline & Jumlah & 60 Orang & 100 \\
\hline
\end{tabular}

Berdasarkan Tabel 1, saluran pemasaran yang paling banyak digunakan oleh peternak susu segar sapi perah di Kecamatan Mojosongo adalah saluran III yaitu sebanyak 30 peternak atau $50 \%$. Pada saluran III pedagang pengumpul melakukan kegiatan pemasaran dengan membeli susu segar sapi perah dari konsumen, selanjutnya susu segar sapi perah dibeli oleh pedagang besar untuk dijual kepada industri pengolahan susu. Pada Saluran pemasaran II dan III peternak lebih condong untuk menjual susu segar kepada pedagang pengumpul sehingga dalam pemasaran lebih mudah dan efisien karena jumlah yang banyak dan kualitas susu segar cepat menurun.

Biaya Pemasaran, Margin, Keuntungan dan Farmer's Share pada Pemasaran Susu Segar Sapi Perah di Kecamatan Mojosongo

Besarnya biaya pemasaran susu segar sapi perah pada saluran pemasaran I, saluran II, dan saluran 3 dapat dilihat pada Tabel 2. Berdasarkan hasil analisis biaya pemasaran, saluran I mengeluarkan biaya terendah yaitu $\mathrm{Rp} 0,00$ sedangkan biaya pemasaran tertinggi terdapat pada saluran III yaitu Rp476,00 dan biaya pemasaran pada saluran II sebesar Rp110,00. Saluran pemasaran II dan III pada dasarnya sama, tetapi pada saluran II pedagang pengumpul memasarkan susu segar ke konsumen langsung sedangkan pada saluran III kegiatan pemasaran di salurkan ke pedagang besar kemudian ke industri pengolahan susu. Berdasarkan hal ini, dapat disimpulkan bahwa saluran I merupakan saluran yang paling efektif karena tidak mengeluarkan biaya pemasaran sama sekali.

Keuntungan pemasaran susu segar di Kecamatan Mojosongo pada setiap lembaga pemasaran berbeda-beda. Hal ini dikarenakan setiap lembaga pemasaran menetapkan harga yang tidak sama. Keuntungan pemasaran yang terbesar terdapat pada saluran III yaitu Rp324,00 karena memiliki lembaga pemasaran yang paling banyak. Saluran I memiliki keuntungan pemasaran terendah yaitu Rp0,00 karena pada saluran I tidak ada lembaga pemasaran yang terlibat dan keuntungan pemasaran pada saluran II sebesar Rp290,00. 
Tabel 2. Rata-rata Biaya Pemasaran Susu Segar pada setiap Saluran Pemasaran.

\begin{tabular}{|c|c|c|}
\hline No. & Uraian biaya & Rp/liter/hr \\
\hline \multicolumn{3}{|c|}{ Saluran Pemasaran I } \\
\hline 1. & Harga jual susu segar oleh peternak & $4.800,00$ \\
\hline 2. & Harga beli konsumen & $4.800,00$ \\
\hline 3. & Farmer's share & $100 \%$ \\
\hline \multicolumn{3}{|c|}{ Saluran Pemasaran II } \\
\hline 1. & Harga jual susu segar oleh peternak & $4.400,00$ \\
\hline \multirow[t]{11}{*}{2.} & Pedagang pengumpul & \\
\hline & a. Harga beli & $4.400,00$ \\
\hline & \multicolumn{2}{|l|}{ b. Biaya pemasaran } \\
\hline & - Transportasi & 54,00 \\
\hline & - Bongkar Muat & 56,00 \\
\hline & Jumlah biaya & 110,00 \\
\hline & c. Harga jual & $4.800,00$ \\
\hline & d. Margin pemasaran & 400,00 \\
\hline & e. Keuntungan & 290,00 \\
\hline & f. Farmer's Share & $91,6 \%$ \\
\hline & \multicolumn{2}{|l|}{ Saluran Pemasaran III } \\
\hline 1. & Harga jual susu segar oleh peternak & $4.400,00$ \\
\hline \multirow[t]{10}{*}{2.} & Pedagang pengumpul & \\
\hline & a. Harga beli & $4.400,00$ \\
\hline & b. Biaya pemasaran & \\
\hline & - Transportasi & 54,00 \\
\hline & - Bongkar Muat & 56,00 \\
\hline & - Retribusi pasar & 125,00 \\
\hline & Jumlah biaya & 235,00 \\
\hline & c. Harga jual & $4.800,00$ \\
\hline & d. Margin pemasaran & 400,00 \\
\hline & e. Keuntungan & 165,00 \\
\hline \multirow[t]{10}{*}{3.} & Pedagang Besar & \\
\hline & a. Harga beli & $4.800,00$ \\
\hline & b. Biaya pemasaran & \\
\hline & - Transportasi & 61,00 \\
\hline & - Bongkar Muat & 55,00 \\
\hline & - Retribusi pasar & 125,00 \\
\hline & Jumlah biaya & 241,00 \\
\hline & c. Harga jual & $5.200,00$ \\
\hline & d. Margin pemasaran & 400,00 \\
\hline & e. Keuntungan & 159,00 \\
\hline \multirow[t]{4}{*}{4.} & a. Total biaya pemasaran & 476,00 \\
\hline & b. Total margin pemasaran & 800,00 \\
\hline & c. Total keuntungan & 324,00 \\
\hline & d. Farmer Share & $84,6 \%$ \\
\hline
\end{tabular}

Margin pemasaran diperoleh dari selisih harga beli konsumen dengan harga yang diterima peternak. Besarnya margin pemasaran setiap lembaga pemasaran dipengaruhi oleh biaya dan keuntungan pemasaran yang diambil oleh setiap lembaga pemasaran. Saluran pemasaran yang memiliki nilai margin pemasaran tertinggi adalah saluran III yaitu Rp800,00 sedangkan margin pemasaran terendah terdapat pada saluran I yaitu $\mathrm{Rp} 0,00$ dan saluran pemasaran II memiliki margin pemasaran sebesar Rp400,00. Saluran III memiliki tingkat efisiensi terendah karena 
memiliki nilai margin pemasaran paling tinggi dibandingkan dengan ketiga saluran lainnya. Estiyati (2010) menyatakan bahwa semakin rendah margin pemasaran, semakin tinggi bagian yang diterima petani (farmer's share) dan semakin pendek saluran pemasaran maka pemasaran semakin efisien.
Efisiensi Pemasaran Susu Segar Sapi Perah di Kecamatan Mojosongo

Perbandingan total biaya, keuntungan, margin pemasaran dan Farmer's share dapat dilihat pada Tabel 3.

Tabel 3. Perbandingan Total Biaya, Keuntungan, dan Total Margin Pemasaran pada setiap Saluran Pemasaran Susu Segar Sapi Perah di Kecamatan Mojosongo, Kabupaten Boyolali.

\begin{tabular}{clcccc}
\hline No. & $\begin{array}{c}\text { Saluran } \\
\text { pemasaran }\end{array}$ & $\begin{array}{c}\text { Total } \\
\text { biaya } \\
(\mathrm{Rp} / \text { liter/hr })\end{array}$ & $\begin{array}{c}\text { Total } \\
\text { keuntungan } \\
(\mathrm{Rp} / \text { liter/hr })\end{array}$ & $\begin{array}{c}\text { Total margin } \\
\text { pemasaran } \\
(\mathrm{Rp} / \mathrm{liter} / \mathrm{hr})\end{array}$ & $\begin{array}{c}\text { Farmer'sshare } \\
(\%)\end{array}$ \\
\hline 1. & Saluran I & - & - & - & 100,0 \\
2. & Saluran II & 110,00 & 290,00 & 400,00 & 91,6 \\
3. & Saluran III & 476,00 & 324,00 & 800,00 & 84,6 \\
\hline
\end{tabular}

Efisiensi pemasaran secara ekonomi dapat diketahui dari besarnya bagian yang diterima produsen (farmer's share). Pemasaran susu segar dianggap efisien secara ekonomis apabila pada saluran pemasarannya bagian yang diterima peternak (farmer's share) mempunyai nilai tinggi. Abadi (2007) menyatakan bahwa pemasaran dikatakan efisien apabila bagian yang diterima produsen $>50 \%$ dan bila bagian yang diterima produsen $<50 \%$ berarti pemasaran belum efisien.

\section{Travelling Salesman Problem (TSP) Susu Segar} di Kecamatan Mojosongo

Analisis data pada penelitian pemasaran susu segar sapi perah di Kecamatan Mojosongo menggunakan Travelling Salesman Problem (TSP) dengan menentukan jarak, waktu dan biaya minimum. Perbandingan jarak tempuh, waktu perjalanan dan biaya distribusi susu segar sapi perah di Kecamatan Mojosongo dapat dilihat pada Tabel 4.

Tabel 4. Jarak Tempuh, Waktu Perjalanan, dan Biaya Distribusi Susu Segar Sapi Perah di Kecamatan Mojosongo.

\begin{tabular}{cccccc}
\hline \multirow{2}{*}{ Jalur } & \multicolumn{2}{c}{ Jarak Tempuh $(\mathrm{Km})$} & \multicolumn{2}{c}{ Waktu Perjalanan } & \multirow{2}{*}{ Biaya $(\mathrm{Rp})$} \\
\cline { 2 - 5 } & Pagi & Sore & Pagi & Sore & \\
\hline 1 & 15,5 & 15,5 & $42^{\prime} 10^{\prime \prime}: 53$ & $43^{\prime} 13^{\prime \prime}: 26$ & $50.000,00$ \\
2 & 22,3 & 22,8 & $47^{\prime} 47^{\prime \prime}: 56$ & $41^{\prime} 35^{\prime \prime}: 15$ & $62.500,00$ \\
3 & 23,7 & - & $57^{\prime} 16^{\prime \prime}: 20$ & - & $25.000,00$ \\
\hline
\end{tabular}

Rute pemasaran susu dari pedagang pengumpulke industri pengolahan susu sebagai berikut:

1. Jalur 1: Pengumpul $\rightarrow$ (Pos 1-8) $\rightarrow$ KUD Kota Boyolali.
2. Jalur 2: Pengumpul $\rightarrow$ (Pos 1-12) $\rightarrow$ Koperasi Andini Luhur.

3. Jalur 3: Pengumpul $\rightarrow$ (Pos 1-4) $\rightarrow$ KSU Keju Boyolali.

Tabel 5. Rata-rata Jarak Tempuh, Waktu Perjalanan, dan Biaya Distribusi Susu Segar Sapi Perah di Kecamatan Mojosongo, Kabupaten Boyolali

\begin{tabular}{|c|c|c|c|c|c|c|}
\hline \multirow{2}{*}{ Jalur } & \multirow{2}{*}{ Jumlah Pos } & \multicolumn{2}{|c|}{ Jarak Tempuh/Pos (Km) } & \multicolumn{2}{|c|}{ Waktu Perjalanan/Pos } & \multirow{2}{*}{$\begin{array}{c}\text { Biaya/Pos } \\
\text { (Rp) }\end{array}$} \\
\hline & & Pagi & Sore & Pagi & Sore & \\
\hline 1 & 8 & 1,9 & 1,9 & $5^{\prime} 15^{\prime \prime}: 53$ & $5^{\prime} 20^{\prime \prime}: 26$ & $6.250,00$ \\
\hline 2 & 12 & 1,8 & 1,8 & $3^{\prime} 54^{\prime \prime}: 60$ & $3^{\prime} 15^{\prime \prime}: 15$ & $5.200,00$ \\
\hline 3 & 4 & 5,9 & - & $14^{\prime} 15^{\prime \prime}: 20$ & - & $6.250,00$ \\
\hline
\end{tabular}


Menurut Tabel 5 jalur pemasaran paling efisiensi adalah jalur 2 karena pada jalur ini jarak tempuh yaitu $1,8 \mathrm{~km} /$ pos, waktu perjalanan yaitu 3,35 menit/pos, dan biaya distribusi sebesar Rp5.200,00/pos. Travelling Salesman Problem (TSP) yang terdapat pada jalur pemasaran 2 dinilai lebih efisien dengan rata-rata jarak terpendek, waktu tercepat dan biaya terendah karena pada jalur ini memiliki 12 pos yang harus dilewati. Saluran pemasaran II dan III yang melalui pedagang pengumpul lebih efektif dan efisien menggunakan jalur 2 karena pada jalur ini membutuhkan jarak, waktu dan biaya terendah.

\section{KESIMPULAN}

Saluran Pemasaran Susu Segar Sapi Perah yang digunakan produsen di Kecamatan Mojosongo terdapat tiga saluran sebagai berikut Saluran I: Peternak $\rightarrow$ Konsumen, Saluran II: Peternak $\rightarrow$ Pedagang pengumpul $\rightarrow$ Konsumen dan Saluran III: Peternak $\rightarrow$ Pedagang pengumpul $\rightarrow$ Pedagang besar $\rightarrow$ Industri pengolahan susu. Jalur pemasaran paling efisien adalah jalur 2 karena pada jalur ini memiliki jarak terdekat, waktu tercepat untuk menjaga kualitas susu segar serta efisiensi biaya.

\section{DAFTAR PUSTAKA}

Abadi, F.N. 2007. Analisis Pemasaran Keripik Tempe di Kecamatan Sambungmacan Kabupaten Sragen. Skripsi S1 Program Studi Sosial Ekonomi Pertanian/Agrobisnis Fakultas Pertanian Universitas Sebelas Maret Surakarta.

Badan Penyuluh Pertanian Perikanan dan Kehutanan (BP3K). 2015. Kecamatan Mojosongo dalam Angka. Kecamatan Mojosongo, Boyolali.

BPS (Badan Pusat Statistik) Kabupaten Boyolali. 2014. Boyolali Dalam Angka. BPS. Boyolali.

Ernawati. 1986. Pengaruh Penanganan Lama Penyimpanan terhadap Kualitas Air Susu Sapi. Media Peternakan Vol: 50-59. Fakultas Peternakan, Institut Pertanian Bogor. Bogor

Estiyati, I. 2010. Analisis Pemasaran Belimbing Manis (Aveerhoa Carambola L.) di Kabupaten Jepara. Program Studi Agribisnis Fakultas Pertanian Universitas Sebelas Maret, Surakarta.
Permadi, G. 2008. Analisis Tataniaga Kambing Peranakan Ettawa (PE) di Kabupaten Purworejo, Jawa Tengah. Program Studi Ekonomi Pertanian dan Sumberdaya. Fakultas Pertanian. Institut Pertanian Bogor, Bogor.

Utomo, H.T., Pulungan, M.H., \& Maryani, S. 2004. Minimasi Biaya Distribusi TempeDengan Menggunakan Metode Travelling Salesman Problem (TSP) (Studi Analisa Usaha Kecil Hikma Sanan-Malang). Jurnal Teknologi Pertanian. 5(2), 87-94. 